\title{
Pediatric rhinitis risk factors (Review)
}

\author{
YAOFENG JI, YIN LIU and NA YANG \\ Department of Otolaryngology, Xuzhou Children's Hospital, Xuzhou, Jiangsu 221002, P.R. China
}

Received February 9, 2016; Accepted September 1, 2016

DOI: 10.3892/etm.2016.3684

\begin{abstract}
Rhinitis is a common global disorder that impacts on the quality of life of the sufferer and caregivers. Treatment for pediatric rhinitis is empirical and does not include a detailed history of the allergy triggers or allergy testing. Thus, allergen avoidance advice is not tailored to the child's sensitivities, which may result in adenoid hypertrophy. However, infant onset rhinitis, especially its relationship with respiratory viruses, remains to be further clarified. Rhinitis basically involves inflammation of the upper nasal lining, presenting typically with symptoms of runny nose (rhinorrhea), nasal blockage, and/or sneezing. While not typically fatal, it does impose significant health, psychological, and monetary burden to its sufferers, and is thus considered a global health problem. Previous findings showed that immunotherapy had significant clinical efficacy in children with allergic rhinitis. The present review article aims to highlight recent perspectives pertaining to the rhinitis risk factors especially in pediatric patients.
\end{abstract}

\section{Contents}

1. Introduction

2. Genetics and heritability factors

3. Environmental exposures

4. Inhalant allergens

5. Nutrition and diet

6. The role of microbial exposures

7. Role of respiratory virus infection in rhinitis

8. Conclusion

\section{Introduction}

Young infants are often observed to be affected by typical sickness symptoms including runny nose (rhinorrhea), nasal blockage, and/or sneezing and are linked with common

Correspondence to: Dr Yin Liu, Department of Otolaryngology, Xuzhou Children's Hospital, 18 Sudibei Road, Xuzhou, Jiangsu 221002, P.R. China

E-mail: liuyin3636@sina.com

Key words: rhinitis, rhinorrhea, respiratory virus, allergens, risk factors childhood problems, such as rhinitis (1-3). The main causative mechanism observed that constitutes a causative factor behind all these symptoms is inflammation. Rhinitis is a disorder that has not been as extensively studied as its other allergic counterparts such as asthma and eczema (4). However, it is possible that the clinical manifestations of rhinitis may precede the development of atopy/allergen sensitization. Thus, further research into rhinitis in early childhood is necessary to understand the beginnings of this disorder. The present review article aims to highlight latest developments of the field with special reference to risk factors involved. The review article may be useful for researchers in updating their knowledge pertaining to the present status and future requirements of this pathological state.

\section{Genetics and heritability factors}

Several studies have attempted to investigate the role of genetic variants in early childhood rhinitis susceptibility (5-7). However, the contribution of genetic factors in the development of early childhood rhinitis has been mostly shown by its heritability. Indeed, parental histories of atopic symptoms are among the most consistently reported risk factors of early childhood rhinitis (8-10). This heritability was further reinforced by a twin cohort study, which evidenced the higher concordance of preschool rhinitis among monozygotic twins as compared to dizygotic twins (11).

\section{Environmental exposures}

The rising prevalence of allergic diseases across the globe (12) suggests that affluent lifestyle and environmental risk factors may also influence the development of rhinitis. As rhinitis is a disease of the upper airways, its association with airborne irritants, such as tobacco smoke, and pollutants is of particular interest. Previous findings have shown that tobacco exposure during pregnancy or after birth did not increase the risk of early childhood rhinitis $(13,14)$. By contrast, the CCAAPS cohort reported that families who smoked a total of 20 cigarettes/day were at an increased risk for rhinitis (ISAAC definition) at 1 year of age (15). However, a follow-up of the cohort reported no association with allergic rhinitis (symptoms with sensitization) at 3 years (14). Tobacco exposure was later reported to be associated with the transient rhinitis phenotype albeit not with the more persistent cough/rhinitis phenotype characterized by the PARIS cohort (16). However, further studies are required to investigate the role of pre- and 
post-natal tobacco exposure. Additionally, to the best of our knowledge, at present, there have not been any studies from birth cohort studies on traffic pollution associated with infant onset rhinitis.

\section{Inhalant allergens}

The role of indoor factors such as inhalant allergens from house dust is also of interest for research in this area. Investigators of the Perinatal Asthma and Environment Long-term Allergy Study (PAULA) (8) cohort measured dust mite allergen levels from dust samples collected from mattresses and living room floors at 3 months of age. While higher dust allergen levels were a risk for the development of dust mite sensitization, it was not found to be associated with current rhinitis symptoms (ISAAC definition) at 4-5 years. Investigators of the Manchester Asthma and Allergy Study (MAAS) cohort measured allergens found within dust samples (collected at birth, 3 and 5 years from parents' and child's bed, child's bedroom and lounge room floor) and related these levels to current rhinoconjunctivitis at 5 years (13). The total dust allergen levels were reported to have an inverse association with rhinoconjunctivitis in non-sensitized subjects in the univariate analysis. However, the association with dust allergen levels was lost after statistical adjustment using multivariate analysis. As such, reduction of dust allergen exposure may not protect and instead increase the risk of sensitization (17), which may then result in subsequent respiratory atopic disorders.

\section{Nutrition and diet}

The influences of nutrients and feeding have been widely investigated. The type 1 Finnish Diabetes Prediction and Prevention (DIPP) cohort conducted a comprehensive analysis of the role of pregnancy (18) and early life nutrition patterns (19) on preschool rhinitis. The result of those studies showed that early introduction of fish in the diet showed protection against preschool rhinitis (20). Furthermore, vitamin D plays a role in the development and regulation of the immune system. However, changes in lifestyle, such as decreased outdoor activities and sunlight exposure leads to lower vitamin D metabolism, which has been suspected to contribute towards the rise of allergic diseases (21). Several studies have addressed the role of vitamin D in the development of preschool rhinitis. On the other hand, Bäck et al (22) reported an absence of association between vitamin D intake levels in infancy with rhinitis at 6 years of age. Furthermore, there are studies that support the idea that higher maternal vitamin D intake from food during pregnancy ensures protection against the development of rhinitis (23-25). Thus, there is clear-cut inconsistency in observations. The reason for this inconsistency is unclear and the protective effect of supplemental vitamin D intake in preschool rhinitis remains controversial.

Breast-feeding is strongly recommended for its numerous benefits to newborns. However, its role in rhinitis development is disputed, as many studies showed no effects of prolonged breastfeeding on early childhood rhinitis (26-28). However, a cohort study reported protective effects of breast-feeding against rhinitis at 3 years, albeit only among African-American individuals (14). These findings suggested that the protective effect of breast-feeding on early childhood rhinitis may be dependent on ethnicity as well as regional practices and views.

\section{The role of microbial exposures}

The 'hygiene hypothesis', initially proposed by Strachan, postulated that the increasing prevalence rates of atopic diseases over the past few decades may be due to decreased early childhood infection, which in turn is related to smaller household sizes, more affluent lifestyles and increased hygiene (29). That author suggested that the absence of early life exposure to infections resulted in a 'lack' of anti-infection Th1 response and consequently, a loss of downregulation of the pro-inflammatory Th2 response. Substantiating this hypothesis is a recent publication by Strachan on the phase 3 (follow-up) ISAAC study (from 31 countries), which showed an inverse association between number of siblings and rhinitis at 6-7 years (30). This association was especially the case for affluent countries, which may advocate that protective effects of siblings are stronger in a 'cleaner' environment.

In contrast to the hygiene hypothesis, previous studies have reported that respiratory viral infections instead predisposed to preschool-age asthma. Results from the COAST (Childhood Origin of Asthma) (31), Perth (32), Copenhagen Studies on Asthma in Childhood (COPSAC) (33), and Wheezing Illnesses Study Leidsche Rijn (WHISTLER) (34) cohorts have shown that early respiratory viruses infection [in particular with human rhinovirus (HRV)] was linked to future development of persistent wheeze or asthma. Due to the close relationship between rhinitis and wheezing, it it is possible that an association exists between respiratory virus infection and rhinitis.

\section{Role of respiratory virus infection in rhinitis}

The link between early childhood infections and preschool rhinitis outcomes has been previously investigated. Thomson et al (35) reported an absence of correlation between gastroenteritis or lower respiratory tract infections in the first 2 years with current allergic rhinitis at 6 years of age. The LISA birth cohort ( $n=1,690$ analyzed) reported that while concurrent middle ear infection (OME) was associated with allergic rhinitis at 6 years, this was not the case for OME at earlier age (0-2 years) (36). A case control study based on a primary care database record (37) reported that of 30 common infections (including upper respiratory infection), only bronchiolitis was significantly protective against later cases of hay fever within 5 years of age. Only a few studies have directly investigated the link between detection of specific respiratory viruses on early childhood rhinitis. The Canadian Asthma Primary Prevention Study (CAPPS) cohort (38) reported a significant association between parainfluenza and enteroviral infections and rhinitis (defined as 'runny nose or sneezing without apparent cold') in the first year of life. That study may have, however, inadvertently included cases of infectious rhinitis (cold/flu) as they reported a prevalence of rhinitis in the first year of life to be $95 \%$.

A case-control study by García-García et al (39) investigated the effect of human metapneumovirus (HMPV) and respiratory syncytial virus (RSV) infections in the first 2 years on the 
development of rhinitis in 3-5 years. There were numerically higher rates of allergic rhinitis in the HMPV (21.7\%) and RSV infected groups $(21.9 \%)$ compared to the uninfected control group (16.7\%). However, these differences were not statistically significant. The study may not have been adequately powered due to small sample size in each group (23-32 subjects/group). As allergic rhinitis was not the primary endpoint of their study, the association was not further explored.

\section{Conclusion}

Despite varying prevalence, rhinitis in early childhood (infancy and preschool; 0-6 years) appears to be a common problem. Studies have shown that heritable factors, such as parental history of atopic diseases, as well as personal presence of atopic co-morbidities, and sensitization are associated with rhinitis in this age group. Environmental exposures and nutrition may also influence the development of rhinitis in early life, albeit with less consistent findings compared to the innate factors. It is likely that there are gene-environmental interactions, and that the effects of environmental exposures depend on the innate susceptibility for developing the disorders. Respiratory viruses have been suggested to lead into the development of preschool age wheeze and asthma; nevertheless, its role on infancy and preschool rhinitis development remains a relatively unexplored area which is to be investigated in future.

\section{References}

1. Bousquet J, Khaltaev N, Cruz AA, Denburg J, Fokkens WJ Togias A, Zuberbier T, Baena-Cagnani CE, Canonica GW, van Weel C, et al; World Health Organization; GA(2)LEN; AllerGen: Allergic rhinitis and its impact on asthma (ARIA) 2008 update (in collaboration with the World Health Organization, GA(2)LEN and AllerGen). Allergy 63 (Suppl 86): 8-160, 2008.

2. Roberts G, Xatzipsalti M, Borrego LM, Custovic A, Halken S, Hellings PW, Papadopoulos NG, Rotiroti G, Scadding G Timmermans F, et al: Paediatric rhinitis: position paper of the European Academy of Allergy and Clinical Immunology. Allergy 68: 1102-1116, 2013.

3. Garg N and Silverberg JI: Association between childhood allergic disease, psychological comorbidity, and injury requiring medical attention. Ann Allergy Asthma Immunol 112: 525-532, 2014.

4. Zheng T, Yu J, Oh MH and Zhu Z: The atopic march: progression from atopic dermatitis to allergic rhinitis and asthma. Allergy Asthma Immunol Res 3: 67-73, 2011.

5. Chen RF, Huang HC, Ou CY, Hsu TY, Chuang H, Chang JC Wang L, Kuo HC and Yang KD: MicroRNA-21 expression in neonatal blood associated with antenatal immunoglobulin E production and development of allergic rhinitis. Clin Exp Allergy 40: 1482-1490, 2010.

6. Kayserova J, Sismova K, Zentsova-Jaresova I, Katina S Vernerova E, Polouckova A, Capkova S, Malinova V, Striz I and Sediva A: A prospective study in children with a severe form of atopic dermatitis: clinical outcome in relation to cytokine gene polymorphisms. J Investig Allergol Clin Immunol 22: 92-101, 2012.

7. Wei X, Zhang Y, Fu Z and Zhang L: The association between polymorphisms in the MRPL4 and TNF- $\alpha$ genes and susceptibility to allergic rhinitis. PLoS One 8: e57981, 2013.

8. Illi S, Weber J, Zutavern A, Genuneit J, Schierl R, Strunz-Lehner C and von Mutius E: Perinatal influences on the development of asthma and atopy in childhood. Ann Allergy Asthma Immunol 112: 132-139, 2014.

9. Alm B, Goksör E, Thengilsdottir H, Pettersson R, Möllborg P, Norvenius G, Erdes L, Aberg N, Wennergren G: Early protective and risk factors for allergic rhinitis at age $4 \frac{1}{2}$ yr. Pediatr Allergy Immunol 22: 398-404, 2011.
10. Nwaru BI, Takkinen HM, Niemelä O, Kaila M, Erkkola M, Ahonen S, Haapala AM, Kenward MG, Pekkanen J, Lahesmaa R, et al: Timing of infant feeding in relation to childhood asthma and allergic diseases. J Allergy Clin Immunol 131: 78-86, 2013.

11. van Beijsterveldt CE and Boomsma DI: Genetics of parentally reported asthma, eczema and rhinitis in 5-yr-old twins. Eur Respir J 29: 516-521, 2007.

12. Asher MI, Montefort S, Björkstén B, Lai CK, Strachan DP, Weiland SK and Williams H; ISAAC Phase Three Study Group: Worldwide time trends in the prevalence of symptoms of asthma, allergic rhinoconjunctivitis, and eczema in childhood: ISAAC phases one and three repeat multicountry cross-sectional surveys. Lancet 368: 733-743, 2006.

13. Marinho S, Simpson A, Lowe L, Kissen P, Murray C and Custovic A: Rhinoconjunctivitis in 5-year-old children: a population-based birth cohort study. Allergy 62: 385-393, 2007.

14. Codispoti CD, Levin L, LeMasters GK, Ryan P, Reponen T, Villareal M, Burkle J, Stanforth S, Lockey JE, Khurana Hershey GK, et al: Breast-feeding, aeroallergen sensitization, and environmental exposures during infancy are determinants of childhood allergic rhinitis. J Allergy Clin Immunol 125: 1054-1060.e1, 2010.

15. Biagini JM, LeMasters GK, Ryan PH, Levin L, Reponen T, Bernstein DI, Villareal M, Khurana Hershey GK, Burkle J and Lockey J: Environmental risk factors of rhinitis in early infancy. Pediatr Allergy Immunol 17: 278-284, 2006.

16. Rancière F, Nikasinovic L, Bousquet $\mathrm{J}$ and Momas I: Onset and persistence of respiratory/allergic symptoms in preschoolers: new insights from the PARIS birth cohort. Allergy 68: 1158-1167, 2013.

17. Holt PG and Thomas WR: Sensitization to airborne environmental allergens: unresolved issues. Nat Immunol 6: 957-960, 2005.

18. Nwaru BI, Erkkola M, Ahonen S, Kaila M, Kronberg-Kippilä C, Ilonen J, Simell O, Knip M, Veijola R and Virtanen SM: Intake of antioxidants during pregnancy and the risk of allergies and asthma in the offspring. Eur J Clin Nutr 65: 937-943, 2011.

19. Nwaru BI, Takkinen HM, Kaila M, Erkkola M, Ahonen S, Pekkanen J, Simell O, Veijola R, Ilonen J, Hyöty H, et al: Food diversity in infancy and the risk of childhood asthma and allergies. J Allergy Clin Immunol 133: 1084-1091, 2014.

20. Magnusson J, Kull I, Rosenlund H, Håkansson N, Wolk A, Melén E, Wickman M and Bergström A: Fish consumption in infancy and development of allergic disease up to age $12 \mathrm{y}$. Am J Clin Nutr 97: 1324-1330, 2013.

21. Rueter K, Siafarikas A, Prescott SL and Palmer DJ: In utero and postnatal vitamin D exposure and allergy risk. Expert Opin Drug Saf 13: 1601-1611, 2014

22. Bäck O, Blomquist HK, Hernell O and Stenberg B: Does vitamin $\mathrm{D}$ intake during infancy promote the development of atopic allergy? Acta Derm Venereol 89: 28-32, 2009.

23. Erkkola M, Kaila M, Nwaru BI, Kronberg-Kippilä C, Ahonen S, Nevalainen J, Veijola R, Pekkanen J, Ilonen J, Simell O, et al: Maternal vitamin D intake during pregnancy is inversely associated with asthma and allergic rhinitis in 5-year-old children. Clin Exp Allergy 39: 875-882, 2009.

24. Baïz N, Dargent-Molina P, Wark JD, Souberbielle JC and Annesi-Maesano I; EDEN Mother-Child Cohort Study Group: Cord serum 25-hydroxyvitamin D and risk of early childhood transient wheezing and atopic dermatitis. J Allergy Clin Immunol 133: 147-153, 2014.

25. Rothers J, Wright AL, Stern DA, Halonen M, Camargo CA Jr: Cord blood 25-hydroxyvitamin D levels are associated with aeroallergen sensitization in children from Tucson, Arizona. J Allergy Clin Immunol 128: 1093-1099.e1-5, 2011.

26. Sandini U, Kukkonen AK, Poussa T, Sandini L, Savilahti E and Kuitunen M: Protective and risk factors for allergic diseases in high-risk children at the ages of two and five years. Int Arch Allergy Immunol 156: 339-348, 2011.

27. Smit HA, Pinart M, Antó JM, Keil T, Bousquet J, Carlsen KH Moons KG, Hooft L and Carlsen KC: Childhood asthma prediction models: a systematic review. Lancet Respir Med Dec 3: 973-984, 2015.

28. Wei JL: Chronic nasal dysfunction in children: Allergic rhinitis? Infectious? What to do if neither? Curr Opin Otolaryngol Head Neck Surg 23: 491-498, 2015.

29. Strachan DP: Family size, infection and atopy: the first decade of the 'hygiene hypothesis'. Thorax 55 (Suppl 1): S2-S10, 2000. 
30. Strachan DP, Aït-Khaled N, Foliaki S, Mallol J, Odhiambo J, Pearce N, Williams HC; ISAAC Phase Three Study Group: Siblings, asthma, rhinoconjunctivitis and eczema: a worldwide perspective from the International Study of Asthma and Allergies in Childhood. Clin Exp Allergy 45: 126-136, 2015.

31. Jackson DJ, Gangnon RE, Evans MD, Roberg KA, Anderson EL, Pappas TE, Printz MC, Lee WM, Shult PA, Reisdorf E, et al: Wheezing rhinovirus illnesses in early life predict asthma development in high-risk children. Am J Respir Crit Care Med 178: 667-672, 2008 .

32. Kusel MM, de Klerk NH, Kebadze T, Vohma V, Holt PG, Johnston SL and Sly PD: Early-life respiratory viral infections, atopic sensitization, and risk of subsequent development of persistent asthma. J Allergy Clin Immunol 119: 1105-1110, 2007.

33. Bisgaard H, Hermansen MN, Bønnelykke K, Stokholm J, Baty F, Skytt NL, Aniscenko J, Kebadze T and Johnston SL: Association of bacteria and viruses with wheezy episodes in young children: prospective birth cohort study. BMJ 341: c4978, 2010.

34. van der Gugten AC, van der Zalm MM, Uiterwaal CS, Wilbrink B, Rossen JW and van der Ent CK: Human rhinovirus and wheezing: short and long-term associations in children. Pediatr Infect Dis J 32: 827-833, 2013.

35. Thomson JA, Widjaja C, Darmaputra AA, Lowe A, Matheson MC Bennett CM, Allen K, Abramson MJ, Hosking C, Hill D, et al: Early childhood infections and immunisation and the development of allergic disease in particular asthma in a high-risk cohort: a prospective study of allergy-prone children from birth to six years. Pediatr Allergy Immunol 21: 1076-1085, 2010
36. MacIntyre EA, Chen CM, Herbarth O, Borte M, Schaaf B, Krämer U, von Berg A, Wichmann HE and Heinrich J; LISA Study Group: Early-life otitis media and incident atopic disease at school age in a birth cohort. Pediatr Infect Dis J 29: e96-e99, 2010.

37. Bremner SA, Carey IM, DeWilde S, Richards N, Maier WC, Hilton SR, Strachan DP and Cook DG: Infections presenting for clinical care in early life and later risk of hay fever in two UK birth cohorts. Allergy 63: 274-283, 2008.

38. Lee KK, Hegele RG, Manfreda J, Wooldrage K, Becker AB, Ferguson AC, Dimich-Ward H, Watson WT and Chan-Yeung M: Relationship of early childhood viral exposures to respiratory symptoms, onset of possible asthma and atopy in high risk children: The Canadian Asthma Primary Prevention Study. Pediatr Pulmonol 42: 290-297, 2007.

39. García-García ML, Calvo C, Casas I, Bracamonte T, Rellán A, Gozalo F, Tenorio T and Pérez-Breña P: Human metapneumovirus bronchiolitis in infancy is an important risk factor for asthma at age 5. Pediatr Pulmonol 42: 458-464, 2007. 